\title{
Isolation and Identification of Glucoamylase Producer Fungus from Sago Hampas
}

\author{
Alfi Asben", Tun Tedja Irawadi* \\ \# Department of Agricultural Product Technology, Faculty of Agricultural Technology, Andalas University \\ E-mail:alfi_asben@yahoo.com \\ * Department of Chemistry, Faculty of Mathematics and Natural Sciences, Bogor Agricultural University \\ E-mail: tuntedja_ipb@yahoo.com
}

\begin{abstract}
Waste of sago processing, notably hampas (ela) still contains sago starch is waste that has not been utilized optimally yet and causing pollution. Isolation and identification of glucoamylase producer fungus of sago hampas waste were aims to obtain isolates that have gluco-amylolytic properties, and to know glucoamylase activity of selected fungus isolates after grown on artificial medium. Indegeneous isolates that can produced glucoamylase will be use to get sugar hidrolysate from starch of sago hampas waste for bioetanol production. The study was conducted with the following stages: 1)Take the sample from the tennis, 2) Isolation and Identification, 3) Characterization (clear zone), and 4) The production of glucoamylase from selected isolates, The results obtained are: 1) Isolation of fungi gluco-amylolytic from 2 sources sago hampas were produced 10 isolates. Ten isolates were divided into 4 genuses: Gliocladium (as dominant isolate), Aspergilus, Rizhopus and Geotrichum. Isolates of Gliocladium KE gaves the largest degradation of starch on PDA-Starch medium (clear zone), and followed by isolates of Aspergillus GA; 2) Production of glucoamylase on sago hampas with modificated Danial medium (1992) gave the highest activity of Gliocladium KE -on the fifth day of incubation, namely: 10.72 U / mL of crude enzyme from the supernatant of fermentation substrate (S), and $17.16 \mathrm{U} / \mathrm{mL}$ for crude enzyme from the extract of isopropanol isolation $(E)$.
\end{abstract}

Keywords—Sago hampas; isolation; Gliocladium KE; glucoamylase

\section{INTRODUCTION}

Sago (Metroxylon sp) is a native plant of Indonesia, believed to originate from the area around Lake Sentani, Jayapura regency, Papua. Sago grows well on marginal land such as peat, swamps, brackish or flooded land where other cros cannot grow [1] Sago waste formed of stem bark and waste the rest of sago starch extraction (ela) are available in abundant quantities and up to now have not utilized optimally, so that still pollute the environment. The field of Indonesian sago is 1,128 million ha or $51.3 \%$ of the area of sago world [2].

According [3], the ratio of starch and sago hampas residues of the extraction process is 1: 6 . The number of sago hampas as solid waste currently depends on the process of extraction, which the ratio of starch to the hampas is estimated to be 1: 4 or 1: 5. According [4], sago waste biomass (hampas) is an organic material which is wasted in large amount after sago processing. 1 ton of waste pith of sago will obtained $800 \mathrm{~kg}$. The other sago processing wastes, such as bark (about 17-25 percent of the weight of the stem) and hampas (ela) accounted for approximately $72 \%$ of the sago palm, is waste that has not been utilized optimally and can cause pollution [5]. Utilization of sago waste can reduce the potential for environmental contamination and provide additional value to the sago crop. Sago hampas is lignocellulosic starchy products obtained through the processing of sago starch (Metroxylon sagu Rottb). Sago hampas is one of the agricultural wastes which can still be utilized for nutritional source of microorganisms [6].

The sago hampas biomass is byproducts lignoselulose containing starch obtained from the extraction process of sago starch. Sago hampas biomass is still a raw organic material very abundant in Indonesia. The main content of the pulp is sago starch (40-60\%) and cellulose (20-40\%). According [7], the cellulose content of the pulp was $22 \%$ sago and starch content was about $51 \%$.

Sago hampas nutritional analysis of the Mextroxilon genus made by [8], reported that: $0.62 \%$ crude protein, $0.4 \%$ fat, $4.65 \%$ ash, $72.45 \%$ starch, and ADF $13.42 \%$. According to analysis [9], sago hampas containing $53.92 \% \mathrm{C}, 0.045 \mathrm{~N}$, $12.02 \% \mathrm{P}, 0.69 \% \mathrm{~K}, 1-3 \% \mathrm{Ca}, 0.01 \% \mathrm{Mg}, 22.1 \%$ cellulose and $14.3 \%$ hemicelluloses. 
Utilization of sago hampas waste into high-value materials can be hydrolyzed sago hampas into sugar hydrolyzate. The piles of sago hampas in the tennis has naturally degraded by the presence of certain microbes, mold and mildew. Result of degradation sugar from starch or cellulose solutions that exist in the sago hampas. Starch is the largest component of the sago hampas; some microbes have the ability to degrade starch (gluco-amylolytic) are Aspergillus niger and Rizhopus sp. These microbes can produce glucoamylase as metabolism [10]. Because of the high starch content in the sago hampas, many types of microbes will grow where glucoamylase producer can be isolated.

Funguses (fungi), microscopic plants having no chlorophyll, live as parasites in the bodies of living creatures, or as a saprophyte on dead organic matter [11]. A Glucoamylolytic fungus is a fungus that can change starch into simple sugars such as glucose. The fungus isolation producing glucoamylase from sago hampas piles, intended to be able to produce controlled potential isolates that can be utilized to degrade the starch of sago hampas into sugar hydrolyzate for further industrial use (exp bioetanol). Isolation of the fungus can be carried out appropriately in accordance with the location where they come from; there are several ways to isolate the fungus in accordance with the origin of their existence. Isolation of fungus soil can be done with spread method, pour method and stick method [12].

Generally, identification of fungus can be done in microscopic and macroscopic method. Microscopic fungus identifies using a microscope after grown in the appropriate medium. While macroscopic observations are observing the growth of fungus generally like the pattern of growth including color formed from the formation of hyphae themselves.

The process of potential microbial (fungus) isolation and identification that is gluco-amylolytic from sago hampas pile is one of the best explorations to get potential fungus, which can be applied in the process of degradation of sago hampas into hydrolyzation sugar for both industrial use glucose production and late production as bioethanol. The form of sago hampas residue found in the tennis looks like soil texture, so the approach is the isolation and identification refers to the isolation of fungus soil. The methods of isolation of fungus in the field is spread method. The result of isolates is identified in macroscopic and microscopic (slide culture). Isolates characterized by clear zone method using PDA -starch medium isolates to determine the most potential isolates to produce glucoamylase.

This research aims to: 1) Getting gluco-amylolytic isolates (containing glucoamylase) from sago hampas residue, and 2) Recognizing the glucoamylase activity of fungal isolates selected after grown on artificial medium.

\section{METHODS}

\section{A. Sampling}

Field sampling Subarang village, Pariaman $(\mathrm{K})$ is done with the following procedure: Sample taken using clean and sterile equipment. Number of samples had taken at least 50 ounces which aseptically inserted into a plastic bag (sterile bottle) and sealed. During the trip the sample is stored in a container with a low temperature $\left(5-8{ }^{\circ} \mathrm{C}\right)$. Sample stored at low temperature $\left( \pm 5^{\circ} \mathrm{C}\right)$ before doing. Sago hampas samples from Seram Island Maluku (G) is the sago hampas samples that have been stored for 2 months in a plastic bag with water level high enough that was $\pm 25 \%$. These samples were previously dried for 3 days under the sun and it has not totally dried.

\section{B. Isolation (spread method)}

Sample preparation procedure: 1) Prepare a series of test tubes containing $9 \mathrm{ml}$ of physiological saline. 2) Sago hampas $5 \mathrm{~g}$ Erlenmeyer included in the flask contains $45 \mathrm{~mL}$ of dilution (physiological saline). 3) Erlenmeyer flask shaken with shaker 10-15 minutes until the estimated mycelium or fungus spores from sago hampas suspended in solution. 4) The suspension was diluted several times in a test tube prepared in step 1, until the last tube containing 500 to 1000 cells / spores were active.

Isolation Procedure: 1) Amount of $0.1 \mathrm{~mL}$ liquid suspension at 3 levels last dilution (diluted $10^{-2}-10^{-5}$ ), put in a Petri dish already containing agar (PDA + chloramfenicol). 2) Suspension leveled the surface, so by using a glass rod ends bent (right angle). 3) Incubate at the temperature of 27$29^{\circ} \mathrm{C}$ up to 5 days. Observe the growth of start day I. 4) Furthermore, select few types of fungus that grows predominantly in Petri dish (after spores came out). 5) Inoculate spores on the surface that the cup that prepared previously (PDA + chloramfenicol), with scratching method. 6) Reisolate in Petri dish and agar slant (modification of Darwis and Sunarti method [12].

\section{Identification}

Identification form of observations of the growth of selected bacteria which include: visual appearance of fungus colonies (macroscopic), and the appearance under the microscope for each of the different colonies after day 5 (microscopic; slide culture). Observations were made using a microscope with a magnification of $40 \times 10$.

\section{Characterization}

Characterization of glucoamylase producing isolates conducted by testing the growth of selected isolates on PDA - starch medium, in the following manner: Prepared PDA starch medium by dissolving $1 \%$ soluble starch in Petri dish. Inoculate fungal isolates selected in the identification and incubate $27-29^{\circ} \mathrm{C}$ for 5 days. On day 5 was pouring a solution of $1 \% \operatorname{Iod}\left(\mathrm{KIO}_{3}\right)$ on the surface Petri dish to know the clear zone formed around the fungal colony that declared the glucoamylase activity.

\section{E. Multiplication and glucoamylase production by selected bacteria}

Propagation isolates were conducted from sago hampas substrate with the addition of mineral solutio. Sago hampas starch obtained from sago processing in Pariaman City (middle Pariaman). Sago hampas used lack the moisture content $(\mathrm{MC}) \pm 12 \%$, size $<100$ mesh. A total of $25 \mathrm{~g}$ of sago hampas substrate was added $40 \mathrm{~mL}$ of mineral solution (modification fomula Danial [13], in a $500 \mathrm{~mL}$ Erlenmeyer flask. Sterilization at $121^{\circ} \mathrm{C}$ for 20 minutes. Inoculate as much as $10 \%$ inoculation in medium substrate, where spore 
isolates have been previously calculated by haemocytometer. Incubation was performed at room temperature for 2-7 days. Humidity chamber maintained at room temperature incubation and incubation note. After 2-7 days of incubation harvesting. Isolation of glucoamylase according modification method Sunaryanto [14], where crude enzyme from the supernatant of fermentation substrate called $S$, and crude enzyme from the extract of isopropanol isolation namely E. Glucoamylase analysis performed based on the method of Pandey et al., [14].

\section{RESULT AND DISCUSSION}

\section{A. The isolation process and macroscopic-microscopic identification}

Glucoamylase-producing fungi isolation process was done 2 times. The first isolation process did with insulation materials derived from Subarang village, middle Pariaman district. Isolate code given is $\mathrm{K}$. The first isolation produced 3 different fungal colonies initially. After re-isolation then identified macroscopic and microscopic (slide culture) obtained 2 different types, where to fungi results isolate $\mathrm{KB}$ and $\mathrm{KC}$ gave the same identification results. Both types of fungi were then coded $\mathrm{KB}$.

The process of isolation second (II), conducted from 2 isolation material that are 1) Sago hampas had been through 2 months of storage from Seram, Maluku (code G) and 2) isolation materials from Subarang village, Pariaman West Sumatra (code K). Isolation II (two) produced 8 fungal isolates with different appearances fungal growth on the isolation medium at the beginning. The eight isolates obtained was coded GA, GB, GC, KC, KD, KE KF and KG. 8th different isolates estimated then it's purified (reisolation), some of which provide similar identification results. It is known that $\mathrm{KB}$ and $\mathrm{KC}$ isolates were the same from the first isolation than $\mathrm{KC}$ isolate herein after omitted and written isolates derived from isolation II. Based on microscopic observations and refer to the book [15], the isolation of fungi from sago waste isolation material produced 4 groups (genus) is Gliocladium fungal isolates (obtained at most) also known as Trichoderma artaviridae, Giotrichum, Aspergillus and Rhizopus.

Macroscopic and microscopic observations on one of the isolates are Gliocladium KE isolates can be seen in Figure 1, which is the appearance on the macroscopic view (A) and the microscopic (B). On the identification of macroscopic (A) seen colony isolates have the display; colony shows middle yellow, orange green at the edge, spreading colony growth, colony surface smooth, medium grew to be flushed, and form irregular colonies. At the microscopic identification (B) with the slide culture method 40 x 10 magnification (Olympus CX 21 (Binoculars), gave results which septa hyphae, white hyaline conidiophores (somewhat murky) and conidia rounded shape. Refer to [15] of macroscopic and microscopic identification of the isolates $\mathrm{KE}$ can belong to the genus Gliocladium, as Gliocladium KE. The Glioladium on the other genus is also known by the name of Trichoderma artaviridae.

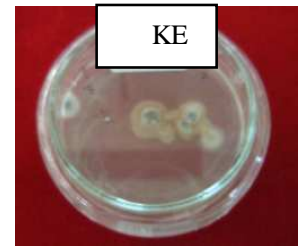

(A)

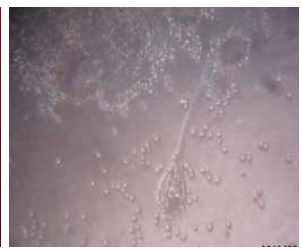

(B)
Fig. 1 Macroscopic and microscopic observations on one isolate of isolation result (Gliocladium KE isolates)

\section{B. Characterization of the clear zone testing on PDA-Starch medium}

Testing of starch degradation by fungal isolates performed using PDA -starch medium. Isolates having the ability to degrade starch with glucoamylase form will provide a clear zone around the colony growth. The test results clear zone glucoamylase-producing fungal isolates from sago waste isolation material can be seen from Table 1.

Forming clear zone by fungal isolates of isolated sago waste showed that Gliocladium KE giving the comparison clear zone diameter / colony diameter was high with the formation of a clear zone around the colony clear and dominant. Geotrichum KB isolate clear zone that has a value slightly higher than Gliocladium KE isolate but did not establish a clear zone around the colony clear and dominant. This Geotricum KB isolate colony growth has spread so the formation of clear zone is rather difficult to measure due to the growth of the colony. Clear zone formed is unstable and is not dominant (blurred). Formation of a clear zone on Gliocladium KE isolate can be seen in Fig.2

TABLE I

MEASUREMENT RESULTS CLEAR ZONE OF FUNGAL ISOLATES ISOLATED FROM SAGO HAMPAS

\begin{tabular}{|l|l|l|l|l|}
\hline No & $\begin{array}{l}\text { Isolate } \\
\text { Code }\end{array}$ & \multicolumn{1}{|c|}{ Genus } & $\begin{array}{l}\text { Hydrolysis (Clear } \\
\text { Zone / Colony) }\end{array}$ & Specification \\
\hline 1 & KA & Gliocladium & - & $(-)$ \\
\hline 2 & KB & Geotrichum & $2.116 \pm 0.055$ & $(+/-)$ \\
\hline 3 & GA & Aspergillus & $1.233 \pm 0.071$ & $(+)$ \\
\hline 4 & GB & Rhizopus & - & $(-)$ \\
\hline 5 & GC & Gliocladium & $1.197 \pm 0.222$ & $(+)$ \\
\hline 6 & KC & Gliocladium & $1.000 \pm 0.000$ & $(+/-)$ \\
\hline 7 & KD & Gliocladium & $1.040 \pm 0.014$ & $(+/-)$ \\
\hline 8 & KE & Gliocladium & $1.290 \pm 0.045$ & $(+)$ \\
\hline 9 & KF & Gliocladium & $1.197 \pm 0.014$ & $(+/-)$ \\
\hline 10 & KG & Gliocladium & $1.071 \pm 0.101$ & $(+/-)$ \\
\hline
\end{tabular}

Note: (+) The establishment of a clear and dominant clear zone around the colony, (-) Not forming clear zone (+ / -), Unstable colony, not real clear zone formation around colony 


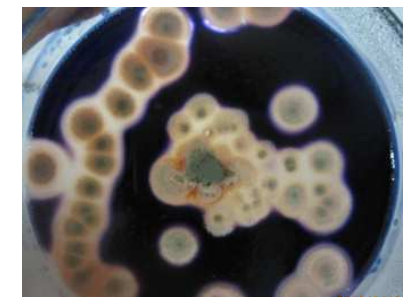

Fig. 2 The results of clear zone formation from Gliocladium KE isolates (B)

\section{Glucoamylase enzyme production}

Glucoamylase-producing fungal isolates selected (Gliocladium KE) refreshed. The amount of fungus spores obtained from the calculation for the production of enzymes by haemocytometer is ranging between $3 \times 10^{8}-4 \times 10^{8}$ spores / $\mathrm{mL}$. Number of spores of this size is sufficient to be used for the production of glucoamylase in the medium modification Danial [13]. Spores grow well.

Glucoamylase production performed on the sago hampas substrate with the addition of mineral solution. Sago hampas used is the dregs of the village Subarang, Pariaman, dried and reduced in size to $<100$ mesh. A number of sago hampas substrate is added minerals solution according to Danial fomula [14] Inoculate as much as $10 \%$ of isolate Gliocladium KE on inoculation medium. Incubation was performed at room temperature for 2-7 days. After incubation harvesting glucoamylase contained in the solution medium.

Picture of Gliocladium KE isolates growth in the modification medium Danial [13] can be seen in Figure 2. While the results of glucoamylase production of Gliocladium KE isolate on a substrate of sago hampas from Subarang village Pariaman shown in Table 2.

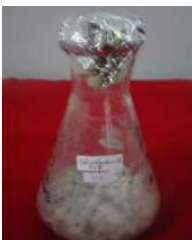

(A)

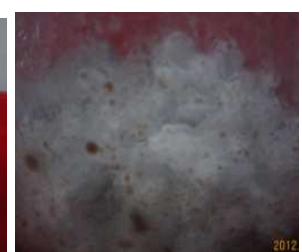

(B)
Fig. 3 Glucoamylase production in $500 \mathrm{~mL}$ Erlemenyer flask (A) and Gliaclodium KE growth to produce glucoamylase used a modified medium Danial (1996) with a 5-day incubation

TABLE III

GLUCOAMYLASE PRODUCTION IN SAGO HAMPAS SUBSTRATE SUBARANG VILLAGE, PARIAMAN

\begin{tabular}{l|l|r|r|r|}
\hline \multirow{2}{*}{ No } & \multirow{2}{*}{ Sample } & Day & \multicolumn{2}{|c|}{ Glucoamylase U / mL } \\
\cline { 3 - 5 } & & & $\mathrm{S}$ & $\mathrm{E}$ \\
\hline 1 & S1D-2P & 2 & 3.01 & 1.74 \\
2 & SID-1P & 3 & 4.31 & 6.74 \\
3 & SIDoP & 4 & 6.90 & 11.82 \\
4 & SID1P & 5 & 10,72 & 17.16 \\
5 & SID2P & 6 & 3,21 & 3.91 \\
6 & SID3P & 7 & 2,09 & 3.40 \\
\hline Note: & S = Crude glucoamylase from supernatant substrate, E = Crude \\
\multicolumn{4}{l}{ glucoamylase from isolation with isopropanol }
\end{tabular}

Highest production of glucoamylase obtained on 5day, which the result of fermentation crude extract (S) was 10.72 $\mathrm{U} / \mathrm{mL}$, and the crude extract after isolated with isopropanol
(E) is $17.16 \mathrm{U} / \mathrm{mL}$. Glucoamylase isolation process has not been going well so that activities on extract isolation results with isopropanol are still low. Modification medium Danial [13] have not been so appropriate in inducing the formation or production of glucoamylase at medium sago hampas. It is required better medium containing nitrogen and other elements more suitable for the production of glucoamylase.

\section{CONCLUSIONS}

Glukoamilolik fungal isolation of 2 sources sago hampas produced an estimated 10 isolates can glucoamylase. Ten isolates were divided into 4 genuses: those Gliocladium (Trichoderma atraviridae) are dominant, Aspergillus, and Geotrichum and Rizhopus. Isolation from sago waste sources Subarang village, Pariaman West Sumatra produce 7 isolates namely: Gliocladium KA, Geotrichum KB, Gliocladium KC, Gliocladium KD, Gliocladium KE, Gliocladium KF, and Gliocladium KG. Isolation from sago waste sources Seram Malaku produced 3 isolates namely: Aspergillus GA, Rizhopus GB and Gliocladium GC.

Gliocladium KE isolate providing a breakdown product of starch (clear zone), the largest in the PDA -starch medium, followed by isolate of Aspergillus GA.

Glucoamylase production in the modification Danial medium (1992) gave the highest activity on the time of Gliocladium KE incubation for 5 days ie; $10.72 \mathrm{U} / \mathrm{mL}$ of the supernatant for enzyme fermentation substrate (S), and $17,16 \mathrm{U} / \mathrm{mL}$ for the isolation of the enzyme extract with isopropanol ( $\mathrm{E})$.

Suggestion, (1) Glucoamylase production process of Gliocladium KE isolates using a medium solution more appropriate. (2) Testing and characterization of glucoamylase produced Gliocladium KE isolate.

\section{ACKNOWLEDGMENT}

Thanks to the Director General of Higher Education was financing this research through DIPA FATETA Research Program, Andalas University in 2012.

\section{REFERENCES}

[1] H.M.H. Bintoro. Bercocok Tanam Sagu. Bogor Sekolah Pascasarjana IPB Bekerjasama dengan Universitas Tokyo.IPB Press. 2008

[2] L. Abner dan Miftahorrahman. 2002. Keragaan Industri Sagu di Indonesia. Warta peelitian dan Pengembangan Tanaman Industri 8(1). http://perkebunan.litbang.deptan.go.id/warta\%20vol\%208\%20no\%20 1\% 20juni\%2020002.htm , 2002

[3] F. J. Ramalatu, Distribusi dan Potensi Pati Beberapa Sagu (Metroxylon sp) di Daerah Seram Barat (Karya Ilmiah). Fakultas Pertanian/Kehutanan yang Berafiliasi dengan Fakultas Pertanian IPB. Bogor, 1981

[4] R. Teti, N. Mindawati, M.Suharti dan Pratiwi, Teknik Penanaman Sagu. Pusat Penelitian dan Pengembangan Kehutanan Bogor, 1989

[5] M. Syakir, Potensi Limbah Sagu Sebagai Amelioran da Herbisida Nabati pada Tanaman Lada Perdu. Disertasi. IPB. Tidak dipublikasikan, 2005

[6] A. Asben, Bahan-bahan dan Senyawa-senyawa yang Potensial Sebagai Sumber Karbon dalam Formulasi Media Fermentasi. 2000. Paper. Fak. Pertanian. Unand Padang, 2000

[7] A. Asben, T.T. Irawadi, K. Syamsu, N. Haska, and T. Kokugan, Sago Hampas'Cellulose Conversion to Glucose In Batch Fermentation. The 10th International Sago Symposium. Bogor. Indonesia.29-30 Oktober 2011.

[8] H.M.H. Bintoro, B. Hariyanto, T. Horigone, M.P. Marangkey, E. Sakaguchi, dan Y. Takamura, Feeding Value of Pith and Pith 
Residue from Sago Palm. Okayama: Proceding Takahashi-Shi Nutrition Conference. P 1-12, 1990

[9] F. .Rumawas, A. Astono, S.A. Aziz dan R.E. Rinhewa, Utilizing Sago Press Cake as Compost. In: Jose C, Rayad A, editors. Sixth Internatonal Sago Symposium. Pekanbaru, 9-12 Desember 1996. Hal165-169, 1996

[10] Nigam et al. Enzyme and Microbial System Involved In Starch Processing. Enzyme Microb Technol. 17: 770-778, 1995

[11] H.. Semangun, Pengantar Ilmu Penyakit Tumbuhan. Gadjah mada University Press, 1996
[12] A. A . Darwis dan T.C Sunarti, Teknologi Mikrobial. Dekdikbud. Dirjen DIKTI. PAU Bioteknologi IPB, 1992.

[13] M . Danial, Evaluasi Potensi Hidrolitik Enzim Selulase dan Glukoamilase dari Campuran Filtrat Kultur A. niger dan T. koningii. Tesis. Program Pascasarjan IPB. Bogor, 1996.

[14] R .Sunaryanto, Produksi, Isolasi, dan Karakterisasi Glukoamilase dari Isolat Lokal Aspergillus niger BSC Menggunakan Substrat Dedak dan Tapioka. Tesis. Program Pascasarjana IPB. Bogor, 2003

[15] H. L. Barnett and B.B Hunter, Illustrated genera of imperfect fungi. Third edition. Burgess Publishing Company. Minesota, 1972 